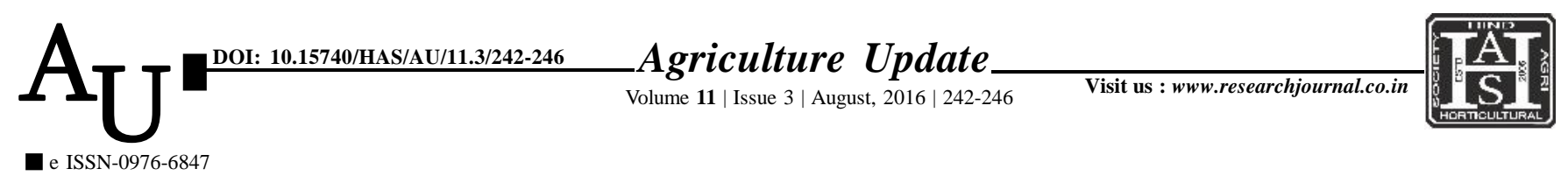

\title{
Rеgеárн Aвтісі: Knowledge levels and adoption pattern of rice production technology among the Navsari district farmers
}

\.A. SHAH, B.M. TANDEL, PRABHU NAYAKA AND C.K. TIMBADIYA

Article Chronicle:

Received :

05.06.2016;

Revised :

26.06.2016;

Accepted :

07.07.2016

KEY WoRDS :

Knowledge level,

Extension gap,

Scientific production,

Technological gap

Author for correspondence :

\section{B.M. TANDEL}

Krishi Vigyan Kendra, Navsari Agricultural

University, NAVSARI (GUJARAT) INDIA

See end of the article for authors' affiliations
SUMMARY : Knowledge of farmers plays an important role in adoption of scientific package of practices. The present study was conducted in Navsari district of South Gujarat during year 2011 to 2013 to study the overall knowledge levels and adoption pattern of rice production technology. Total 200 respondents were selected. The results of overall knowledge of scientific cultivation practices of paddy indicated that farmers having low, medium and high level before contact with KVK was 73 per cent, 20 per cent and 7 per cent, respectively but it was altered up to 19 per cent, 67 per cent and 14 per cent, respectively after contact with the KVK. The study indicated that the about 67.00 per cent of the rice growers had medium level of knowledge, whereas, only 7 per cent of the rice growers had high level of knowledge about scientific cultivation practice of rice. The per cent increase yield of 25.9, 23.03 and 3.0 per cent during the year 2011-12, 32.22, 19.36 and 13.3 per cent during the year 2012-13 and 30.9, 22.1 and 14.5 per cent during the year 2013-14 were found under the paddy variety NAUR-1, GNR-3 and GNR-2 over control (farmer's variety), respectively. Average extension gap was 663, 862 and $831 \mathrm{~kg} / \mathrm{ha}$ during the year 2011-12, 2012-13 and 2013-14, respectively. The average technology gap ranged between $810 \mathrm{~kg} /$ ha to $1268 \mathrm{~kg} / \mathrm{ha}$ during all the three years.

How to cite this article : Shah, K.A., Tandel, B.M., Nayaka, Prabhu and Timbadiya, C.K. (2016). Knowledge levels and adoption pattern of rice production technology among the Navsari district farmers. Agric. Update, 11(3): 242-246, DOI : 10.15740/HAS/AU/11.3/242-246. 